\title{
高次脳機能障害者向け調理ナビゲーションのためのレシピお よび提示メディアの構造化
}

\author{
Structuring Recipes and Media Applicable to a Cooking Navigation System \\ for People with Cognitive Dysfunctions
}

\author{
宮脇 健三郎 ${ }^{\dagger}$, \\ 大出道子柿,
}

佐野睦夫列, 松岡 美保子柿
米 村 俊一计,

Kenzaburo Miyawaki ${ }^{\dagger}$, Mutsuo Sano ${ }^{\dagger}$, Syunichi Yonemura ${ }^{\dagger \dagger}$, Michiko Ode ${ }^{\dagger \dagger \dagger}$ and Mihoko Matsuoka ${ }^{\dagger \dagger}$

\begin{abstract}
A brain injury can cause many cognitive dysfunctions, including aphasia, memory disorder, attention deficit, and so on. Although cooking training programs are popular as a rehabilitation method for people with cognitive dysfunctions, it is difficult to have such individuals perform cooking alone. Ordinary recipes (such as those found in books or TV programs) and existing cooking support systems are not designed with cognitive dysfunctions in mind and require too much capability in terms of comprehension and memory. We have developed a multimedia cooking navigation system that can effectively support individuals with cognitive dysfunctions. The system integrates and displays recipes available in different media, and users can easily choose which media they receive and therefore better understand the cooking procedures. We tested the system by using it in the rehabilitation of a patient, with encouraging results: the patient became more positive about cooking and her feeling of independence was increased.
\end{abstract}

キーワード：高次脳機能障害，調理ナビグーション，リハビリテーション

\section{1. まえがき}

頭部外傷などにより脳に損傷を受けると，言語や記憶な どの認知能力に障害が生じる場合がある。このような障害 は高次脳機能障害と呼ばれ, 様々な症状により日常生活を 困難なものにしてしまう。障害を負った人々は突発的に身 体機能や認知能力を奪われ，今までできていたことができ なくなった自分に苛立ったり，自信を言失して消極的になっ たりすることが多い。

このような高次脳機能障害者に対し，調理行動を通じて

2010 年 3 月 1 日受付, 2010 年 5 月 17 日再受付, 2010 年 6 月 11 日採録 †大阪工業大学 情報科学部

（テ 573-0196 大阪府枚方市北山 1-79-1，072-866-5186)

††NTT サイバーソリューション研究所

（テ 239-0847 神奈川県横須賀市光の丘 1-1，046-859-2265）

††大阪府立障がい者自立センター

( ₹ 558-0001 大阪府大阪市住吉区大領 3 丁目 2-36，06-6692-2971)

$\dagger$ Faculty of Information Science and Technology, Osaka Institute of Technology

(1-79-1, Kitayama, Hirakata-City, Osaka, 573-0196, Japan)

$\dagger \dagger$ NTT Cyber Solutions Laboratory

(1-1, Hikari-no-Oka, Yokosuka-City, Kanagawa, 239-0847, Japan)

†† Osaka Prefectural Self-Reliance Center for Persons with Disabilities

(3-2-36, Dairyou, Sumiyoshiku, Osaka-City, Osaka, 558-0001, Japan )
心身機能の回復を図るリハビリテーションが行われている. 調理は自立した生活を営む上で最も基本的な行動で, 多数 の調理器具, 食材, 調味料を使用し,「切る」「炒める」等 多岐に渡る動作から構成される複雑な夕スクであることか ら，リハビリテーションの題材に適している ${ }^{1)}$.さらに，近 年, 脳機能の活性化を促す作用があることも報告されてい る ${ }^{2) 3)}$.

しかし, 高次脳機能障害の原因となっている脳の物理的 損傷は, 医学的な再建が容易ではなく, 反復学習をしても 短期間で機能回復して自力で調理を遂行することは難しい. そのため, 従来のリハビリテーションでは他者の補助や指 導のもとに調理を完遂することが主目的となっていたが, その場合には, 高次脳機能障害者の自信回復や, 自立促進 にはつながりにくいという課題があった。したがって，脳 機能の活性化を指向するリハビリテーションを行いつつも， 環境の調整等の工夫により，人の手を借りずに調理作業を 完遂させられるよう，障害の特性に合わせて適応的に支援 する必要がある。そのような工夫により，高次脳機能障害 者が, 独力で調理を行えたという達成感を得て, 前向きな 態度を形成し，日常でも調理を行おうとする意欲を持って， 自立した生活と持続的なリハビリテーションが可能になる と期待できる。 
本稿では, 以上のような考えに基づき, 高次脳機能障害 者の心身特性に応じて調理行動を支援するための調理ナビ ゲーションシステムと, システム実現のための, レシピお よび提示メディアの構造化方式を提案する。

高次脳機能障害は, 脳の損傷部位に応じて, 言語の理解 に支障をきたす失語症や, 記憶障害, 注意障害, 夕スクの プランニングができず，物事を順序立てて正しく実行でき ない遂行機能障害などを発症する。情報技術による高次脳 機能障害者の支援に関しては，すでに専用のタスク支援シ ステムが市販されており ${ }^{4) 5}$, スケジューラや仕事の手順 案内等の多彩な機能を有するものの, 使用するメディアは テキストと静止画, 音声が主体で, 調理のような複雑な動 作が要求されるタスクを支援するにはその機能が不足して いる，例えば，失語症のように言語機能が低下すると，テ キストや音声の理解が困難なこともありえるため, 映像に よる動作の教示が必要になるというように, 高次脳機能障 害者がレシピの内容を認知できるメディアは, その障害の 特性や程度によって異なるため, 映像・音声・テキスト等 の複数メディアを統合しておくことが重要である.さらに， 各メディアを通じて獲得した情報を適切に理解してもらう ためには，障害者の記憶や注意の範囲等に配慮するような, 調理レシピの構造化が不可欠である.

日本工業規格 (JIS) によれば，テキストや静止画のよう な, 時間の経過によって内容の変化しないメディアは静的 メディア，映像・音声のように变化するものは, 動的メディ アと呼ばれ，これらのメディアを複数組合せて同時に提示 することをマルチメディアと定義している ${ }^{7)}$. 本研究の目 的達成のためには, 高次脳機能障害の状態に対応した構造 を持つ,マルチメディア調理レシピが要求される.

しかしながら, 高次脳機能障害者のためのマルチメディ ア調理レシピや, 調理を支援するシステムに関する研究例

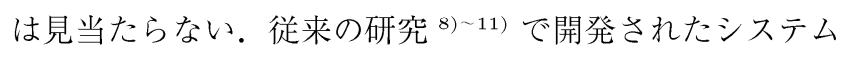
の有効性は, 健常な認知能力を持つユーザに対してしか検 証されておらず, レシピも, 高次脳機能障害者のために適 した構造とはなっていない.これに対し, 本研究では, 調 理レシピを高次脳機能障害者の心身特性に配慮した認知負 担の小さい構造に变換し, また, 静的・動的メディアを効 果的に組合せることで障害者の知覚・認知特性にも配慮す る.そして,このような構造変換された調理レシピを用い ることで, 高次脳機能障害者のための調理ナビゲーション システムを実現する。

我々は, 高次脳機能障害者が調理を行う際に起こりうる 問題点を抽出し, それらを解決できるようシステムコンセ プトを立案した。そして, それに基づいて調理レシピの構 造化方式の提案および, 調理ナビゲーションシステムの設 計を行い, ある高次脳機能障害者を被験者として，そのリ ハビリテーションに適用した. 結果として, 我々のシステ ムは概ね期待通りに利用されて, 効果的な調理支援が実現 でき, 被験者はシステム利用以前よりも積極的に調理に対
して取組めるようになった。

本論文は以下のように構成される。第 2 章で, 高次脳機 能障害者が，一般的レシピや既存システムを用いて調理す る際に起こり得る問題点を説明し, 第 3 章では, それらの 問題に対して, 我々が提案する調理ナビゲーションシステ ムのコンセプトと, システムで用いるマルチメディア調理 レシピの構造について述べる。そして, 第 4 章で提案シス テムを用いたリハビリテーションの観察結果を，第 5 章で 考察を示し, 最後にまとめと今後の課題を述べる.

\section{2. 高次脳機能障害者と調理}

高次脳機能障害者が調理を行う上で, 大きく二つの問題 点がある。一つは一般的なレシピの扱いにくさという, 外 部環境の問題である。もう一つは, 認知機能の低下という 障害に起因する問題である。高次脳機能障害者の調理に対 して有効な支援を行うには，これらの問題点を解消する必 要がある。

ここで，以降の議論を進めやすくするため，次のように 用語を整理する。

(1) 調理

ある手順にしたがって食材を加工する作業.

(2) 料理

調理の結果生成される成果物.

(3) レシピ

調理手順に関する記述.

(4) 調理操作

食材に対して行う, 切る, 混ぜる, 煮るといった種々 の操作 ${ }^{12)}$.

(5) 調理リソース

調理操作では, 多数の調理器具・機器, 食材, 調味 料を用いる。これら, 調理操作に必要とされるもの を一括して調理リソースと呼ぶこととする。

\section{1 レシピが持つ課題}

レシピは様々なメディアで記述されているが, 必ずしも 使いやすいものばかりではない。一般に用いられているレ シピ記述メディアは以下の 2 種である.

（1）静止画像・テキストのように, 時間が経過しても 内容が変化しない, 静的メディア.

(例) 料理本等の印刷物. WEB ページ.

（2）映像のように，時間の経過とともに内容が変化す る動的メディア. (例) テレビの料理番組.

（1）は簡潔に調理手順を説明しており，調理の流れを一覧 することが可能である。しかし，テキストや静止画像では， 各調理操作の連続的な動きを見せられない. その上, 各手 順で要求される調理リソースに関する情報や，その使用方 法は, 常識的な知識として暗黙のうちに省略されている場 合が多く，加熱のタイミング等もテキストでは説明しづら いため, 調理の常識的知識がなければ，レシピを具体的な 行動に翻訳できない. 
一方 (2) は連続的な動きを見せることができ，調理者は 見たままを再現すればよく，静的メディアの欠点を補完し てはいるものの, 一覧性がなく, 調理全体の流れを把握す ることが難しい．また，放っておけばシーンが先に進んで しまうため, 重要な箇所を意識して記憶するか, 適切に停 止・再生・巻き戻しを制御する必要がある。

このように，一般的なレシピは初心者にとって簡単なも のではなく, 認知機能が低下した高次脳機能障害者にとっ ては，さらにその理解が困難なことが容易に予想できる.

\section{2 調理を困難にする機能障害}

高次脳機能障害者が調理を遂行するには，前述した，一 般的レシピに内在する課題に加えて, 様々な機能障害が問 題となる．調理を完遂させるためには，

（1）レシピをもとに各手順の内容を理解し，行動計画 を立案する。

（2）手順で要求される調理リソースを調達する.

（3）手順内容に基づいて調理リソースを適切に使用し, 調理の進行を管理する。

といった過程を経る必要があるが, 高次脳機能障害では多 様な障害のために，上記各プロセスの遂行が困難になる．高 次脳機能障害に含まれる主な障害を次に挙げる ${ }^{13)}$. 高次脳 機能障害者の調理を支援するにはこれらを補完するような 配慮が必要である。

\section{(a) 記憶障害}

記憶には様々な種類がある ${ }^{14)}$ が，調理においては，短期 記憶や作業記憶に関する機能が必須である。これらの機能 が損なわれた場合, 調理をどこまで進めたか, 現在何をし ているのかを失念してしまう可能性がある。また，意味記 憶や手続き記憶も重要である。これらの能力に障害が発生 すると，記憶に基づく調理操作の再現が困難になる.

\section{(b) 注意障害}

注意障害を発症すると, 思考や行為を成立させるために, ある刺激に対して注意を向け続ける持続的注意や，多くの 刺激の中から必要な刺激を選択し, それに集中する選択的 注意，複数の刺激に対して同時に注意を配る，配分的注意 といった機能に障害が生じる ${ }^{14)}$ 。そのため, 作業が長続き しなかったり，失敗が増えたりする。

\section{(c) 遂行機能障害}

遂行機能は日常の問題を計画的・合理的に解決するため の能力である ${ }^{14)}$.この機能に障害が生じると, タスクのプ ランニングやゴール設定が難しくなる. 結果として, 決断 力が低下し，何をしたら良いか決められなくなることがあ る.

(d) 失語症

失語症では, 言語の表出（話す，書く）と受容（聴く, 読 む）に関する働きが阻害される ${ }^{14)}$. 言語の受容機能に障害 が生じると，テキストや音声の読解が困難になり，一般的 なレシピ, 特に静的メディアによるものでは調理手順の内 容を充分に理解できなくなる可能性が高い.

\section{(e) 失行症}

運動器官に問題がないのに行為に失敗する現象である ${ }^{14)}$. 道具や物品の使用方法を間違えたり, 熟練しているはずの 運動行為が拙劣化したりする。

(f) 聴覚失認

音は聞こえるが，その内容がわからなくなる障害であ

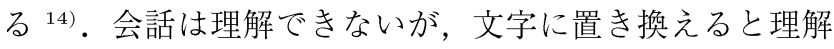
できることがある。

(g) 視覚失認

視覚刺激を適切に処理できず，対象物の形態はとらえて いても，それが何であるかということがわからなかったり， 自分が書いた文字が読めなかったりする. 物体, 画像, 色 彩, 文字, 相貌, といった特定の対象に限って障害が発生 することもある ${ }^{14)}$.

なお, 上記以外の症状として感情や欲求のコントロール が困難になる社会的行動障害 ${ }^{14)}$ も主要症状として挙げら れているが, 現状の提案手法で対処することは難しいため, 今後の課題としたい.

\section{3 既存システムが持つ問題点}

調理を支援するシステムに関しては従来より様々なシス テムの研究・開発が行われている。しかしながら，これら の既存システムでは前節で述べた，様々な認知機能の障害 に対処するのは困難である。

一般に普及しているシステムとして, 携帯型ゲーム機 NINTENDO DS の調理支援ソフトがあるが，それらが提 供するレシピは高次脳機能障害者の心身特性に配慮されて はいない.

例えば,「健康応援レシピ 1000 DS 献立全集」15)では「材 料 $X$ を切って $t$ 分ゆでる.ざるに上げて水気をきり，材料 $Y$ を切る.」というように, 複数の調理操作が 1 手順として まとめて提示されるため，作業がどこまで進んだのかを把 握しづらく, 調理者の混乱を招く恐れがある. 遂行機能障 害を持つ高次脳機能障害者の場合は，夕スクを分割し単純 化することが重要とされており ${ }^{16)}$ ，このような点からも， レシピの構造に問題がある.

「世界のごはんしゃべる！D S お料理ナビ」17) は，レシ ピの記述メディアに，テキスト，静止画，映像，音声を使 用してはいるが，映像による解説は手順の一部にとどまっ ている。しかも, 映像解説は, 調理者が明示的に要求しな い限り提示されないため, 記憶障害の場合は映像を提示す るという操作自体が想起されない可能性がある.

一方，高次脳機能障害者に対する作業支援については，多 数の研究事例があるものの, 調理分野に適用可能な例は見 られない.中山らは高次脳機能障害者の日常生活支援を目 的として PDA 上で動作するソフトウェアを開発し，市販 している ${ }^{4) 5)}$ ・このソフトウェアはタスクの手順をユーザ自 らが入力できるため，作業を細分化し，リスト表示できる が，テキスト，静止画，音声による提示が主体であり，調理 動作の再現には不充分と考えられる。佐々木らは, USB カ 
メラにより高次脳機能障害者の作業を見守り, 作業誤りを 検出してガイダンスを提示するシステムを提案している ${ }^{18)}$ が, 支援対象がブロックの組立て作業であるため, 要求さ れる動作は単純で種類も限定されている. また，このシス テムも, テキスト, 静止画によって情報を提示している.

\section{3. 高次脳機能障害者向け調理ナビゲーションのデ ザイン}

前章では，高次脳機能障害者が一般的なレシピや，既存 の支援システムを用いて, 調理を完遂させようとする際に 起こり得る問題点を述べた。本稿で対象とした高次脳機能 障害を持つ被験者の場合は，一般的な調理本のレシピによ る調理時にこれらの問題点が顕在化し, 独力での調理には 至らなかった，既存の支援システムでも，提示するレシピ が高次脳機能障害者の利用を考慮した構造になっていない 限り，同様の結果になる可能性がある.

本章では，これまでに説明した問題点を解消できるよう に,ナビゲーションシステムのデザインを進める。

\section{1 システムの目標}

本研究の目標は, 高次脳機能障害者が独力で調理を完遂 できるように支援する調理ナビゲーションシステムの実現 である。この目標は, 山内によって提唱された Quality of Life の構成要因 ${ }^{19)}$ を基礎としている。すなわち，

(1) 身体的健康 (健康を維持増進すること)

（2）生活動作 (排泄, 整容, 摂食など身辺処理の他, 移 動, 買い物, 旅行, 娛楽などを含む)

（3）精神生活 (尊厳, 自尊心, 個人的信条- 価值観, 社 会的価值観など)

（4）社会生活 (家族・地域・社会との関係, コミュニ ケーションなど)

の 4 要因の向上である.上記 $(1)(2)$ と調理行動の関係は明 白である.さらに, 独力での調理完遂体験は (3)(4)に対し ても貢献できると考えている，家事労働の中でも重要な地 位を占める調理という仕事を行えるということは, 自信と, 精神的な満足感を生み, 社会参加を促すと期待できる.

以上の考えに基づき, 我々は, 高次脳機能障害者向け調 理ナビゲーションシステムが達成するべき目標を次のよう にまとめた。

目標 (1) 高次脳機能障害者が独力で調理を完遂できるよう に支援する。

目標 $(2)$ 高次脳機能障害者が, システムを利用し, 人手に 頼らず調理を成功させることで, その自己効力感（必要な 行動を効果的に遂行できる可能性の認知 ${ }^{6)}$ ) を高める.

目標 (3) 自己効力感の高揚を通じて, 社会参加を促し, 自 立した生活への足がかりを築く。

\section{2 システムの基本コンセプト}

第 2 章で述べた問題点を解消し, 前述した目標を達成す るため, 我々は, 高次脳機能障害者向け調理ナビゲーショ ンシステムの基本コンセプトを以下のように定めた。

\section{コンセプト (1) 曖昧性が排除されたレシピの提供}

一般的なレシピには, 調理リソースに関する記述や，常 識的知識が省略されていることがある，それらを補完し，具 体的記述にする.

\section{コンセプト $(2)$ 手順の分割}

一つの手順に複数の調理操作が含まれ, 多数の食材の加 工に関して記述されている場合は，それらを分割し，調理 者が一段階ずつ確認しながら調理を進められるようにする。 コンセプト (3) 静・動的メディアを組合せたレシピ提示

2.2 節で説明したように, 高次脳機能障害者が調理の手 順を理解しやすいようにするには, 症状に対応した適切な 構造を持つ調理レシピを, 静的・動的メディアを組合せて 提示する必要がある。また, 提示にあたっては, 動的メディ アの再生は，手順の開始時に自動的に開始し，意識的に要 求するという余計な手間は省く.

\section{コンセプト (4) 調理手順の一覧表示と調理の進行状況の可} 視化

レシピの手順を一覧表示し, 現在, 実施中の手順はどこ なのかを明示する。これにより，高次脳機能障害者が調理 の進行を完全に把握する必要がなく，記憶に対する負荷を 軽減する。

次節以降で，上記のコンセプトに示した，レシピの構造 変換，および，静・動的メディアの組合せ方式と，その具 体的な提示・制御方法を具備したプロトタイプシステムに ついて述べる。

\section{3 レシピの構造変換と記述メディアの組合せ方}

本研究では, 静的・動的メディアを調理手順ごとに分割 し，同時に提示する．静的メディア(テキストおよび静止 画像) は, 調理手順の一覧性を確保し, 高次脳機能障害者 が必要な情報のみを素早く取り出すために使用する。そし て, 動的メディア (映像および音声) は調理操作を直接的に 教示し, 詳細な手の動かし方や器具の扱い方，および動作 のタイミングを明示するために使用する。これにより，高 次脳機能障害者がレシピのテキストの行間を読む手間を省 き, 静的メディアだけでは教示しきれなかった, 調理に関 する常識的かつ暗黙のうちに省略されている知識がなくて も，調理を完遂できるようにする.

手順ごとに分割された両方のメディアは，見比べやすい ように同期させて提示する。つまり，静的メディアによっ て表示されている手順一覧においては, 現在実行中の手順 が一体どこなのかが明確にわかるようにしておき，当該手 順の実施中には, 動的メディアによる教示が, 繰り返し再 生される。あわせて，各手順で使用する調理リソース情報 を手順の説明から分離して漏れなく提示し, 高次脳機能障 害者が，準備するべき器具や食材に関する情報を手順の説 明文から抽出したり，記憶したりするための負荷も軽減す る。分割された手順間は前後に自由に移動でき, 現在の手 順から次の手順に移動すると同時に，その手順の実施方法 が動的メディアで再生される. 高次脳機能障害者にとって 


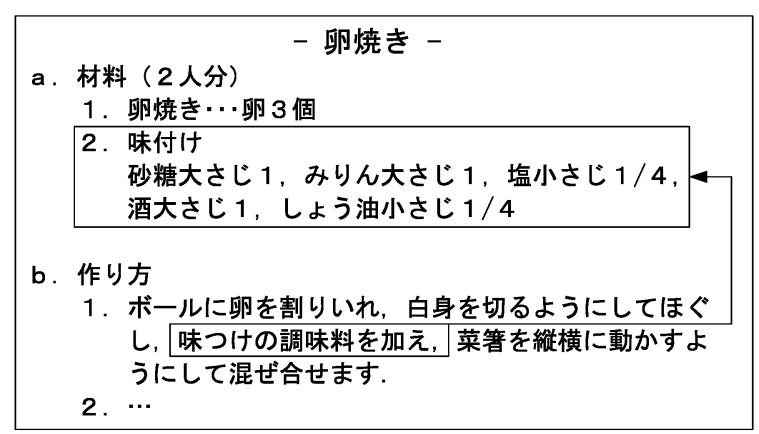

図 1 一般的なレシピの例

An example of a standard recipe.

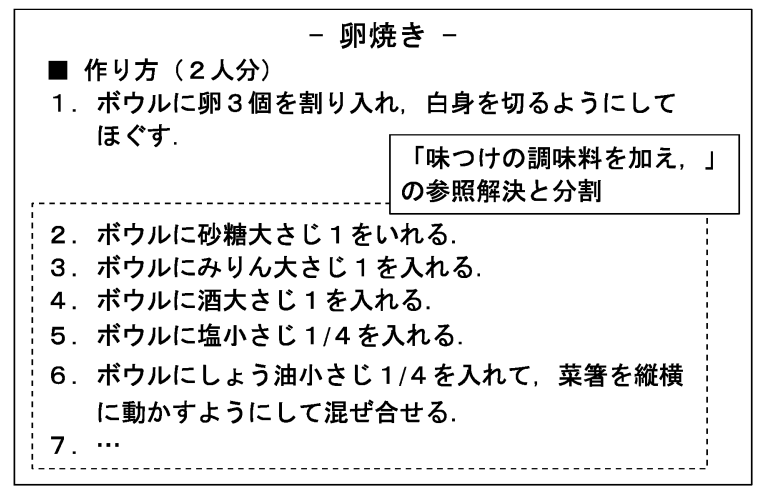

図 2 参照解決と手順分割がなされたレシピの例 An example of a compiled recipe.

は，静的メディアによる記述をつぶさに読解する必要はな く，必要な調理リソースに関する情報だけを取得し，後は 動的メディアが示すとおりに動作を再現すればよい.

なお, 本研究ではレシピの分割は, 切砕, 混合といった 調理操作単位を基本とする.

一般的なレシピでは, 図 1 に示すように, 複数の操作が 一手順に含まれていることが多い. 図 1 のb. 作り方の手 順 1 はレシピ上では一つの手順ではあるが，実際は

(1) 卵を溶く。

（2）卵に味付けの調味料を加える.

という二つの作業から構成されている。このような事例は 多数存在し, しかも, どの程度の作業が一手順に含まれる のかは, レシピによってまちまちである.

また，手順 1 に「味付けの調味料を加え」という一文が あるが，これは，レシピ冒頭に列挙された材料のうち, 調 味料の部分を参照している。このように調理に必要な情報 が分散して配置されていると，作業記憶に関する能力が低 下している高次脳機能障害者に対して負担が大きかったり， 注意障害を持っている場合は注意が分散して, 混乱したり する可能性がある。本研究では, 以上のようなレシピ文に おける参照を全て解決し, 図 2 に示すような手順に分割し たレシと゚を使用する。手順 1 は, 卵を溶く操作と味付けの ための操作に分割され，味付けの操作はさらに個別の調味 料を添加する操作へと展開し, 最終的に 図 2 の手順 $1 \sim 6$ に分割される。このように，情報の提示を調理操作単位に 一貫させて, 分散配置された情報を各手順に埋め込むこと

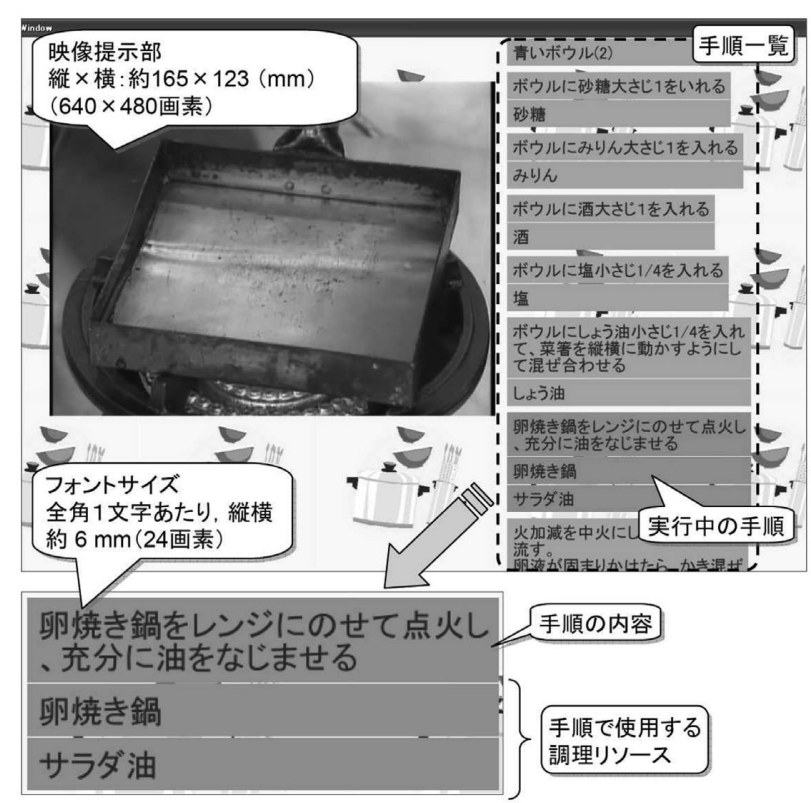

図 3 プロトタイプシステムの画面 A screen shot of the proto-type system.

表 1 表示用モニタの性能 Monitor spec.

\begin{tabular}{l|l}
\hline \hline サイズ & 17 型 \\
\hline 解像度 & $1280 \times 1024(\mathrm{SXGA})$ \\
\hline 表示領域 & $337.9 \times 270.4(\mathrm{~mm})$ \\
\hline 外形寸法 & $(\mathrm{W} \times \mathrm{H} \times \mathrm{D}) 372 \times 369 \times 151(\mathrm{~mm})$ \\
\hline
\end{tabular}

で，ユーザの記憶能力への負担が軽減され，かつ，現在実 行している手順のみに注意を向けるだけでよくなる。

なお，今回は実装上の負荷を軽減するため，以上のよう な手順分割は手動で行った。

\section{4 プロトタイプシステム}

図 3 に調理ナビゲーションシステムのプロトタイプの画 面構成を示す。

プロトタイプシステムでは, 静的メディアにテキストの みを使用している。これは，高次脳機能障害者の場合は，一 度に大量の情報を処理し切れない場合があり，あまり多く の情報が画面上に提示されていると，注意が分散し，かえっ て混乱する可能性があるためである。

画面左に映像提示部，右側に手順一覧表示部を配し，現 在実行中の手順については，テキストの背景色を変化させ て注視すべき部分を明示し，映像提示部では，映像レシピの うちテキストに対応した部分を繰り返し再生する。そして, 各手順のテキスト下部にその手順で使用する調理リソース のリストを提示する。

図 4 に開発した調理ナビゲーションシステムをキッチン に設置した様子を示す。表示用モニ夕には，BENQ 社製 FP72E を使用した。モニタの性能を表 1 に示す。

モニタ, 動画表示領域, フォントのサイズは, 被験者を 交えた予備実験を行い，作業場所と視認性の確保を考慮し て決定した.

システムの操作には，ゲーム機のコントローラを用いる. 


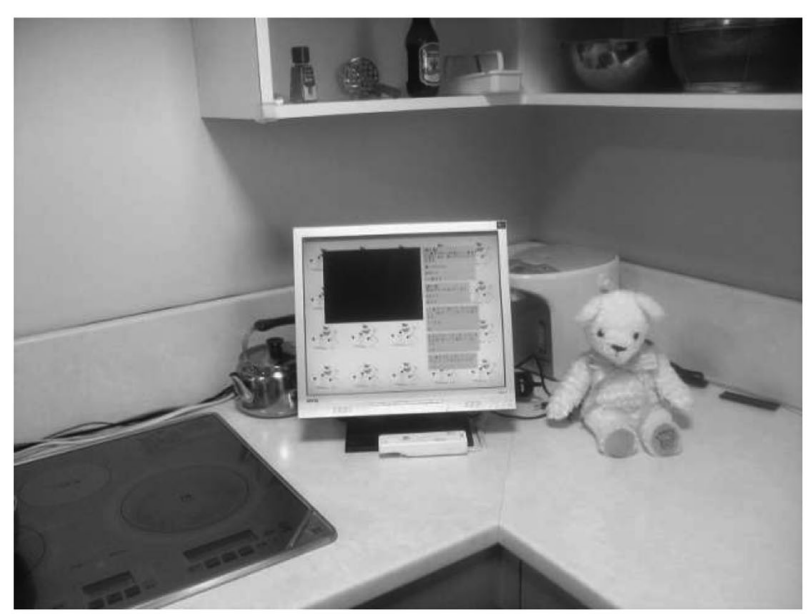

図 4 調理ナビゲーションシステムを設置したキッチン The kitchen with the system.

使用するボタンは二つだけで，レシピの手順を先に進める， 戻すという最低限の操作だけにし，利用者の記憶に負担を かけないようにした。また，ユーザがボタンを押した結果， 映像提示部に示されている手順が進んだり，戻ったりした ことを認識しやすいよう, ボタン操作に合わせて効果音を 鳴らすとともに，合成音声によって「次に進めるよ」「前に 戻るよ」とシステムに発話させた. 画面横の熊型ロボット は，ユーザがシステムに対して，親しみを持てるように設 置したもので，発話時の演出として画面を指し示すジェス チャを行わせた。

\section{4. 調理ナビゲーションシステムを用いたフィール ド検証}

前章までに述べた高次脳機能障害者向け調理ナビゲーショ ンシステムを，実際のリハビリテーション現場で利用し，そ の有効性を検証した。本リハビリテーションプログラムは 4 日間にわたって実施され，システムを用いて 6 回の調理 が行われた。

\section{1 被験者}

被験者は 39 歳の女性である。図 5 に頭部 MRI 画像を 示す.〈も膜下出血のため, 左大脳半球（図 5 の点線枠内） が広範囲に萎縮しており, 左右, 特に左側の著しい脳室拡 大が見られる. 症状に関しては, 失語症に加えて, 記憶, 注 意, 遂行機能等, 知的能力全般に渡って障害が発生してお り, 次のような特徴を有していた。

特徵 (1) 言語理解に関しては聴覚より視覚情報の方が理解 しやすい.

特徵 (2) あいまいな場面の読取りや物事をすばやく処理す ることは不得手.

特徽 (3) 構成力や遂行機能面が弱く, 解決までの筋道を見 つけ出すことが苦手.

特徵 (4) 注意対象をテンポ良く切り替えることが苦手.

特徵 (5) 複数ある指示を覚えておきながら作業すると一つ の課題に没頭しやすい.

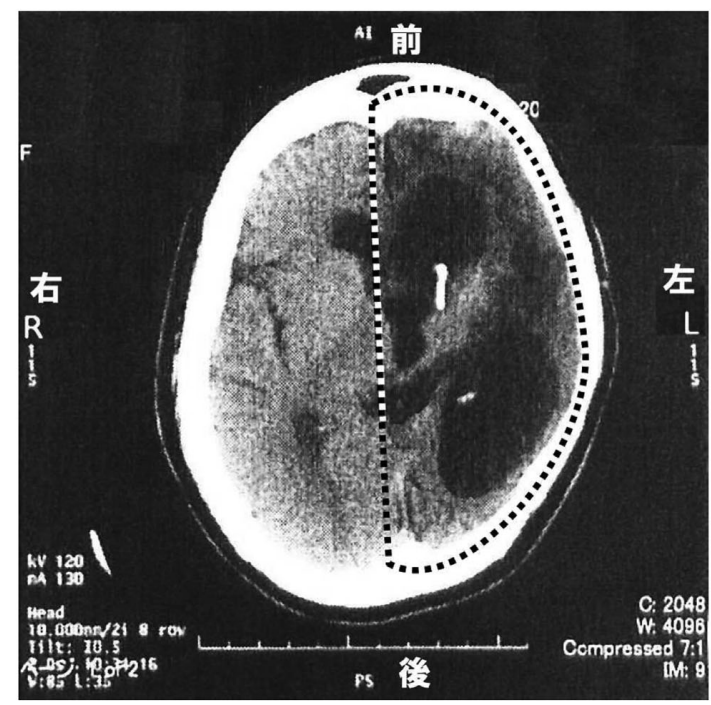

図 5 被験者の頭部 MRI 画像 MRI Images of the Patient.

特徵 (6) 緊張や自信のなさを感じやすい.

特徴 $(7)$ 右半身に軽度の麻痺.

調理に関しては，発症以前は経験がなく，家族の調理を 見たことがあった程度である. 発症後から, 我々のシステ ムを用いるまでには「肉じゃが」「オーブンによる揚げない とんかつ」「とりささみ梅しそ巻き」「餃子」「中華スープ」 の 5 品目で調理訓練を行っている. 調理時間は最長でも 1 時間程度である。いずれも一般的な調理本から抜粋した静 止画像とテキストから構成される紙のレシピで， 3.3 章で 述べたような構造変換はされていない，例えば,「揚げない とんかつ」では「豚肉は $8 \mathrm{~mm}$ の厚さに切り, 両面に塩, こしょうをして耐熱㿼に並べ，30 秒ほど加熱する.」とい うように，レシピ上の一手順に複数の調理操作が存在して いた。この紙レシピによる訓練では，被験者はレシピを確 認しながら調理をしようとしても，手順に関する補足説明 を加えなければ進めることができず，また，テキストの読 み間違いなども発生し, 訓練担当者が常に助けたり, 指示 を与えたりすることが前提になっており，独力での達成は 困難で，自信のある様子は見られなかった。

\section{2 実験用システムの構成}

情報システムを用いた調理訓練は，被験者にとって初め ての体験である。したがって，被験者が画面に提示された 情報をどの程度認知し, 処理できるかどうかは不明であっ たため, リハビリテーションプログラムを前半・後半に分 け，前半 2 日間では， 3.4 節で述べたプロトタイプシステ 厶 (図 3) を用いて, メニューも食材数の少ない比較的簡単 なものを選択し, 後半では, 静的メディアに画像情報を加 えた拡張型システムを用いて, 複雑なメニューを調理して もらうという方針を立てた。

後半の訓練で用いる拡張型システムの画面構成を 図 6, 図 7 に示す。この拡張型システムは, 各調理手順の完成状態 の静止画像をテキストの横に配置して, タスクのサブゴー 


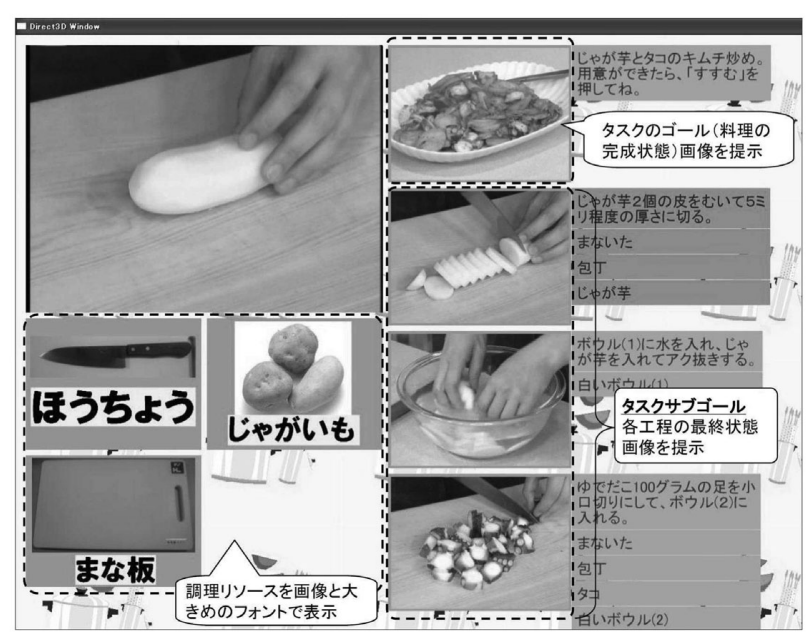

図 6 拡張型システム 1

The enhanced system 1 .

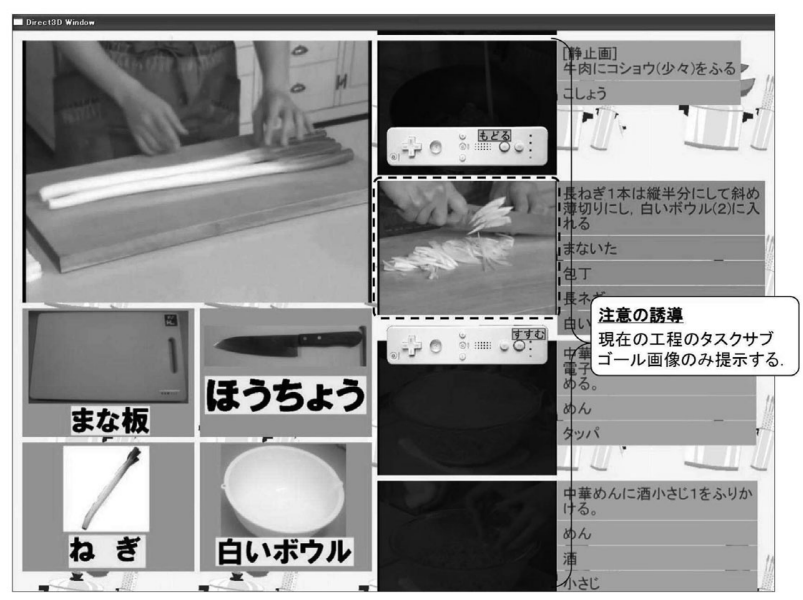

図 7 拡張型システム 2

The enhanced system 2 .

ルを視覚的に明示し，かつ，調理リソース情報を静止画像 と大きめのフォントで提示している。サブゴール画像は各 調理手順の見出しとして機能し, 料理の流れの理解を助け て，ユーザのプランニングを支援する。これと調理リソー ス画像を合わせることで, 手順数や使用する調理リソース 数の多い複雑なメニューであっても調理できるように意図 している。以上の拡張によって，言語的な障害による影響 をプロトタイプよりも軽減させることが期待できるが，反 面, 画像の増加により被験者の注意が分散される危険性も 含んでいる。調理の種類によっては, サブゴール画像によ る見出しの利用によって先々の手順の内容を手軽に予想し, 調理効率を高められる可能性があるが，同時に多くの画像 を同時に提示するということは，被験者に対し必要以上の 注意配分を強いるため, 混乱を招くおそれがある。そこで, 後半の訓練をさらに 2 分割し, すべてのサブゴール画像を 提示する, 拡張型システム 1 (図 6) と, 現在の手順以外の サブゴール画像をマスクすることで，ユーザの注意を誘導 する, 拡張型システム 2 (図 7 ) を順に適用することとした。

\section{3 実験方法}

表 2 に訓練メニューを示す。被験者に対しては特別な指
表 2 訓練用メニュー

Rehabilitation program.

\begin{tabular}{|c|c|c|c|c|c|c|}
\hline 日程 & & 品目 & 手順数 & 食材 & 調味料 & $\begin{array}{l}\text { システム } \\
\text { 構成 }\end{array}$ \\
\hline \multirow[t]{2}{*}{1 日目 } & & 卵焼き & 11 & 2 & 5 & \multirow{4}{*}{$\begin{array}{l}\text { プロト } \\
\text { タイプ } \\
\text { (図 3) }\end{array}$} \\
\hline & (b) & しし唐のナムル & 5 & 3 & 2 & \\
\hline \multirow[t]{2}{*}{2 日目 } & & $\begin{array}{l}\text { ねぎと塩昆布の崩 } \\
\text { し豆腐 }\end{array}$ & 5 & 3 & 0 & \\
\hline & (d) & たたききゅうり & 6 & 2 & 4 & \\
\hline 3 日目 & (e) & $\begin{array}{l}\text { ビゃがいもと夕コ } \\
\text { のキムチ炒め }\end{array}$ & 19 & 5 & 4 & $\begin{array}{l}\text { 拡張型 } 1 \\
(\text { 図 6) }\end{array}$ \\
\hline 4 日目 & (f) & $\begin{array}{l}\text { 牛肉とねぎのオイ } \\
\text { スターソース焼き } \\
\text { そば }\end{array}$ & 18 & 4 & 5 & $\begin{array}{l}\text { 拡張型 } 2 \\
(\text { 図 7) }\end{array}$ \\
\hline
\end{tabular}

示を与えず，ただンステムが提示するレシピを参照してこ れらの品目の調理を進めてもらった。 1 日で 2 品目調理す る場合は，同時並行ではなく，1 品目ごとに完成させた。ま た，表中の食材数については，加熱調理に使用する水やサ ラダ油といった熱伝導媒体も含めている。

なお，4.1節で述べたように，本被験者は調理経験が浅い ため, これらの訓練メニューは全て初めて調理するものであ る、卵焼きのみ，家族が調理する場面を見たことがあった。

実験にあたっては本研究の目的, 趣旨および内容を伝え, 承諾を得た上でシステムを使用してもらい，訓練の様子を ビデオに撮影し分析した. 高次脳機能障害者の症状は多様 であり，同様の障害，症状を持つ被験者を多数集めること は困難である。一方，一人の被験者に対して長時間に渡っ て多くの実験を繰り返し実施することは，心身に対する負 担を考慮すると倫理的に問題がある。したがって，今回は 統計処理を前提とした実験統制は行わず，撮影されたビデ 才映像をもとに，3.2 節で述べた基本コンセプトがどのよ うに機能したかを確認し, ついで, 訓練後の被験者からの インタビュー結果も加えて，3.1節で我々が立てた目標が 達成できたかどうかについて考察することとした。

\section{4 実験結果}

調理品目 (a)〜 (f) の結果を以下に示す.

（1）a. 卵焼き

このメニューでは，コンセプト (3) に基づいて提示して いた動的メディアレシピが，特に，最初の卵を溶く手順と， 加熱工程での油を温める手順において利用された。卵を溶 く手順では, 被験者が映像レシピを頻繁に確認し, 教示さ れている動作を丁寧に参照しながら卵をかきまぜる様子が, そして，油を温める手順では，音声情報をもとにした，適 切な順序での動作の遂行が観察できた。

この油を温める手順は，卵焼き用の鍋を充分に加熱して から，油を注いで鍋になじませるという作業であるが，提 示される映像レシピは, 元になったビデオコンテンツの都 合上，鍋を加熱するシーンが省略され，直ちに鍋に油が注 がれるシーンから開始しており，音声によって「充分に鍋 を熱し，油を入れる」と，動作の順序に関する説明がなさ れている。被験者はこの音声を理解し，冷えた鍋にすぐに 
油を注ぐのではなく, まず, 鍋を充分に加熱し, 次いで油 を注ぐというように正しい順序で動作を実行したのである。 さらに, このとき, 手を鍋の上にかざして温度を確認しつ つ, 映像・音声を視聴するという, 二つの行動を同時に行っ ているところも見られた，また，この手順では使用する油 の分量をテキスト・映像レシピともに明言していなかったた め, 周囲に助言を求めるかと思われた. しかしながら, 映像 レシピにおいて, 余分な油をキッチンペーパで吸収するこ とによって, 油の分量を調節するシーンが示されると, 被 験者は映像の通りに動作を実行し, 油を適量に調節できた のである。

以上のような行動は, 動的メディアによるレシピ提示の 有効性を示唆している. 4.1 節で述べたように, 本被験者 はシステム利用以前の構造化されていない紙のレシピを用 いた訓練では，レシピに書かれた手順を見ても一人で主体 的に実行することができなかったが，上記の行動において， システムによって提示された映像・音声レシピの教示する 通りの行動を, 単独で遂行できている。この結果から, コ ンセプト (3) の効果が伺える.

最終的には卵焼きを無事焼き上げることができた。

(2) b. しし唐のナムル

しし唐や長ねぎの下ごしらえが終了した後，コントローラ のボタンを押し間違え, 前の手順に戻ってしまったが「あっ, 間違えた」とつぶやき, すぐに操作誤りに気づいた，周囲 の指摘を必要とせず気づいたことから, 音声合成や効果音 によるシステムの動作の明示的な通知, あるいは, コンセ プト (4) に基づく実行中の調理手順の強調表示が, きっか けとなった可能性がある。その後は，15 秒程度の時間でレ シピを進め, 正しい手順が表示されている状態にシステム を復旧させた。

調味段階では，しし唐に塩をかけるところを䛊って長不 ギにかけてしまったものの, 音声で塩をしし唐に振りかけ る説明がなされると, 誤りに気づいて訂正できた。 4.1 節 で述べたように，システム利用以前の訓練では紙レシピの 読違え等による誤り発生時には, 周囲の指摘を受けること でそれに気づき, 訂正をしていたが, 本メニューでは音声 レシピの教示によって，自ら誤りに気づき訂正できた。こ れらの比較から, コンセプト (3) が, 誤りを気づかせるこ とに対しても有効である可能性が示唆された。

（3） c. ねぎと塩昆布の崩し豆腐

本メニューは，ねぎ，塩昆布を刻み，豆腐と和えるとい う単純な調理であるが, 昆布を入れる手順では, どの程度 入れたらいいかを周囲に質問した。この料理において塩昆 布は調味料の役割も兼ね, 調理者の好みで量を加減する必 要があり, 分量が指示されていないため, 慎重になってし まったようである。好みで分量を加減する, という指示を 明確に記述するべきであった。自分の好みで調味するよう に助言を与えると, 食材同士を和える段階で, 映像を見な がら自分の判断で塩昆布を追加し, 料理を仕上げた。

\section{（4）d.たたききゅうり}

最初に，食材の下ごしらえできゅうりをすりこ木で吒き 潰す必要があった。半身麻痺の影響によって実行しにくい ようであったが，自力で行えた。

調味料を加えると，あえてモニタの近くに食材の入った ボウルを持って行き，映像を見ながらきゅうりと調味料を 混ぜ合わせて仕上げ，コンセプト (3) に基づく諸機能を頼 りにしている様子が伺えた。

(5) e. じゃがいもと夕コのキムチ炒め

この訓練では, 図 6 の拡張型システム 1 を使用した。じゃ がいもの下ごしらえではいもを落としながらも，丁寧に皮 をむき，映像を確認しながらスライスした，その後の加熱 作業では，ねぎの炒め具合を気にして周囲に確認する等の 慎重さが見られたが，無事に調理を完成させた。

拡張型システムで導入した変更点については, 調理リソー 不画像に対しては, 被験者本人から「どういう器具を使う かを知るために(調理リソース画像は) あった方が良い.」と の感想を得ており，概ね成功であった。しかし，夕スクの サブゴール画像に対しては，被験者が画像を見ながら調理 を進めた場合に，ボタンを押してシステムの状態を先に進 めることを失念してしまい，システムが提示している映像 レシピと, 被験者が認識している調理の進行にずれが生じ るケースが見られ, 本被験者の場合は, サブゴール画像を 全て提示したのでは負担が大きすぎたようであった。

(6) f. 牛肉とねぎのオイスターソース焼きそば

この訓練では, 図 7 の拡張型システム 2 を適用した. 被 験者は，訓練開始後ただちに調理を開始せず，システムを 操作してコンセプト (4) に基づいて表示しておいた, 調理 手順の一覧を閲覧し, 必要な調理リソースを確認後, 調味 料等を前もって準備しはじめた. システム利用以前の訓練 では，手順を進めるたびに周囲の指示や助言を受けて作業 を実施する, という進行が常であったが, そのような状況 と比較すると, 本メニューでは, システムを利用して主体 的かつ段取りよく調理を進めている様子を確認することが でき, コンセプト (4)の有効性が示唆された.

また，中華湎に味付けする手順では，実際に味付けをし たかどうかを思い出すために，映像レシピから流れる「しょ う油小さじ 2 杯」「酒小さじ 2 杯」の音声に同期して画面 を指差しながら念入りに確認しており，音声情報を適切に 利用していた。

仕上げの加熱では，映像を確認しながら，ねぎや麺をフ ライパンにスムーズに追加し, 麺の炒め具合が良いかどう かも自分で判断して, 料理を完成させた.

\section{5 実験のまとめと被験者による主観評価}

各メニューの観察結果からは, マルチメディアレシピが, 被験者に活用されていたことが分かる．4.1節で述べたよ うに, 本被験者は, システム導入以前のリハビリテーショ ンでは，書籍のレシピから抜粋したレシピを用いて訓練を 行っていたが, 調理遂行全般に渡って次に何をすればよい 
表 3 被験者の自己評価

Self evaluation of the patient.

\begin{tabular}{|c|c|c|c|c|c|c|}
\hline 日程 & $x=ュ ー$ & $\begin{array}{l}\text { システム } \\
\text { 構成 }\end{array}$ & 気分 & 意欲 & 理解 & インタビューのまとめ \\
\hline 1 日目 & (a) (b) & \multirow{2}{*}{$\begin{array}{l}\text { プロト } \\
\text { タイプ } \\
\text { (図 3) }\end{array}$} & 5 & 4 & 2 & $\begin{array}{l}\text { 家でもやってみようと } \\
\text { 思った. } \\
\text { 音声が少し早い. }\end{array}$ \\
\hline 2 日目 & $(\mathrm{c})(\mathrm{d})$ & & 5 & 5 & 2 & $\begin{array}{l}\text { 簡単で美味しかった. } \\
\text { 家でもできそうな気が } \\
\text { する. }\end{array}$ \\
\hline 3 日目 & (e) & $\begin{array}{l}\text { 拡張型 } 1 \\
\text { (図 } 6 \text { ) }\end{array}$ & 5 & 4 & 2 & $\begin{array}{l}\text { じゃがいもをどの程度 } \\
\text { きれいにむけばよいか } \\
\text { 分からなかった. }\end{array}$ \\
\hline 4 日目 & (f) & $\begin{array}{l}\text { 㕬張型 } 2 \\
\text { (図 7) }\end{array}$ & 5 & 5 & 4 & $\begin{array}{l}\text { とても良かった. 家に } \\
\text { あったら使いたい. }\end{array}$ \\
\hline
\end{tabular}

のかを指示しなければならない状態であった。しかし，本 システム使用時の訓練では，システムが提示する情報をも とに独力で問題を解決しょうとする姿勢が見られ，混乱し た状況以外では周囲への助言を求めることもなく，すべて の調理を問題なく仕上げた。このようなシステム導入前後 の状況比較からは, 本システムの支援によって, 被験者が 単独で調理を遂行できるようになったことが推測される。

表 3 に被験者本人から聞き取った訓練に対する自己評価 およびインタビューのまとめを示す，自己評価の聞き取り は, 担当のケースワーカによって行われた。表中の気分, 意 欲および理解の項目は以下のような 5 段階評価で， 5 が最 良の評価である。

気分 1 . 全く楽しくなかった〜 5 . とても楽しかった

意欲 1 . とても疲れた〜 5 . まだまだできそう

理解 1. 全くわからない〜 5. よくわかった

表 3 の「気分」「意欲」については，一貫して高い評価をつ けており，調理に対する積極性の高さが確認できる。ささら に，自宅でも調理をしたくなったという発言からは，自立 への強い意向を伺うことができ，システム導入以前の受身 の状態と比較して, 前向きな態度の形成が感じられる, 良 好な自己評価を得ることができた。

訓練メニューは，リハビリテーションが進むにつれて食 材・調味料数が増加し, 手順も複雑になっていったにもかか わらず，最終日に「理解」の項目に対して高い評価をつけ ている。これは，訓練メニューをすべてやり遂げたという 経験によって自信がついたと見ることもできる。また， メ ニュー (e)(f) の観察結果の比較も考慮すると, 本被験者の 場合は, レシピ, 調理リソース, タスクサブゴール，といっ た情報を静・動的メディアによって提示する際は拡張型シ ステム 2 (図 7) で示したような注意の誘導が有効であると いう可能性も示唆されている.

一方, インタビュー結果からは, 音声メディアの再生速 度や，じゃがいもの下ごしらえにおけるタスクサブゴール の提示方法に対し, 若干の課題があったこともわかる. 食 材の下ごしらえをどの程度丁寧に行うかの判断は, 誰に料 理を振舞うかといった周囲の状況も関係するため，一概に
説明することは困難である。本被験者の場合は，リハビリ テーションの一環であるということを意識してか, じゃが いもの下ごしらえを丁寧に行い, 結果として映像レシピで 示されたじゃがいもとほぼ同じ状態にまで至っており, 調 理上の問題はなかったと考えられる.

音声については訓練初日での感想であり, 最終的にはシ ステムの再生速度に慣れたようであるが, 今後, 個人適応 可能な再生速度の制御等について検討したい。

\section{5. 考 察}

本章では，3.1節で挙げた本システムの目標がどの程度 達成されたかを, 観察結果と被験者からのインタビューを もとに考察する。

\section{1 目標 (1) 独力での調理完遂の支援}

前章で述ベたリハビリテーションの観察結果の通り, 我々 が設計したシステムは期待通りに利用され，本被験者は，深 刻な失敗をすることなくすべての料理を仕上げた，完成し た料理は味についても全く問題なく、リハビリテーション プログラムを無事終了できた、特に，メニュー (e)や (f) は 調理に 1 時間以上を要したが, 高い意欲を見せており, 集 中して調理に取組んでいた様子が伺えた。システム導入以 前の訓練では，調理のみに連続して 1 時間以上取組むこと はなく，しかも周囲からの指示を全般的に必要とした。こ のような，短時間の調理でも受身の状態であったシステム 導入以前の訓練を考慮すれば，本システムは，被験者の独 力での調理完遂に対し貢献できたと考えられる。

\section{2 目標 $(2)$ 自己効力感の向上}

メニュー (e)「じゃがいもと夕コのキムチ炒め」は，完 成までに 85 分と，全メニュー中で最も時間がかかったが， 自己効力感の向上を示す典型的な事例が観察された. 本又 ニューに打いて，被験者は，じゃがいもの皮むきと芽取り を，約 30 分かけて非常に丁寧に行っていた. 片腕が不自由 な状態であり，じゃがいもを落とすこともあったため，我々 は, 被験者に対し半身麻瘏患者用のまな板の使用を勧めた。 しかし，被験者は「(普通のまな板で)やれそうう.」提案を 断り, 通常の調理器具だけで上手に下ごしらえした。全体 を通して非常に長時間の調理であったにもかかわらず，終 了後も「さほど疲れていない」と，高い意欲を保持してお り，自信のある様子を見ることができた。このような事例 や, 表 3 のインタビュー結果を総合すると, 被験者本人の 「自分は調理ができる」という自己効力感が向上していると 考えられる。

\section{3 目標 $(3)$ 自立}

自立という側面からは，被験者が自宅で家族に対し，自 分に料理をさせてくれるよう，初めて提案したことが非常 に大きな成果であった，2 日目の訓練終了後「ねぎと塩昆 布の崩し豆腐」の作り方を記憶しており，自宅で自分自身 の手で完成させることができたのである．本被験者は，障 害を負って以来，なかなか家事を担当させてもらえなかっ 
たが，このように同居している家族に対して自己主張でき たことは，極めて重要な変化であり，自己効力感の向上を 通じて自立を促すという, 本研究の期待通りの成果が得ら れたといえる。

\section{6. むす び}

本稿では，高次脳機能障害者の独力での調理を支援する ため, 高次脳機能障害者の心身特性に配慮し, 静 - 動的义 ディアを組合せて適切に構造化されたマルチメディア調理レ シピと, それを用いた高次脳機能障害者向け調理ナビゲー ションシステムを提案した。提案システムを実際に高次脳 機能障害を持つ被験者のリハビリテーションに適用した結 果，被験者は，高い意欲を持って，なるべく他者に依存せ ずに調理を遂行できるようになり，システム適用前よりも 自己効力感が高まっている様子を観察できた。また，家庭 内でも，できる範囲で調理の分担を自ら進んで引き受ける ようになるなど，自立に向かった非常に良い傾向を見るこ ともできた。以上の結果から，本システムによって，我々 が揭げた目標がほぼ達成できたことを確認した。

現在, 我々は新たな被験者のリハビリテーションにもシ ステムを適用しているところである。今後も症例研究を進 めて事例を蓄積し，様々な夕イプの高次脳機能障害者に対 応できるようにシステムを改善して行く予定である。

最後に, 本研究にご協力いただいた，被験者様に深く感謝 する．また，日頃から熱心に議論および実験協力をいたたく 大阪府立障がい者自立センターの小山智美氏，廣畑史子氏， 大槻奈穂氏および辻野㻟也氏に謝意を表する。なお，本研 究の一部は，文部科学省研究費補助金（基盤 C 21500192） の支援を受けた。

\section{〔文献〕}

1）小倉郁子，早川裕子，三村將，穴水幸子，藤森秀子，前野豊，三村將， 穴水幸子：“高次脳機能障害を持つ患者に対する調理訓練の経験”，認知 リハビリテーション, 2007, pp. 40-45 (2007)

2）山下満智子, 川島 隆太, 岩田一樹, 保手浜勝, 太尾小千津, 高倉美香: “調 理による脳の活性化 (第一報)"，日本食生活学誌，18，2，pp.134-139 (2007)

3）山下満智子, 川島隆太, 岩田一樹, 保手浜滕, 太尾小千津, 高倉美香: “調 理による脳の活性化 (第二報)"，日本食生活学誌，17，2，pp.125-129 (2006)

4）明電ソフトウエア株式会社，“高次脳機能障害者のリハビリ・生活・就 労支援ソフト「メモリアシスト」”,

http://talkassist.meidensoftware.co.jp/ma/index.html

5）中山剛, 中井徹志, 横田恒一, 外山滋, 加藤誠志, 岡谷和典, 上田典之, 植松浩: “高次脳機能障害者の日常生活支援を目的とした PDA 用ソフト ウェアの開発”，信学技報 (WIT), 福祉情報工学，103(746), pp.13-18 (2004)

6）成田健一，下仲順子，中里克治，河合千恵子，佐藤眞一，長田由紀子： “特性的自己効力感尺度の検討一生涯発達的利用の可能性を探る-”，教育 心理学研究, 第 43 卷, 3 号, pp. 306-314 (1995)

7）日本工業標淮調查会：“人間工学ーマルチメディアを用いるユーザインタ フェースのソフトウェアー第 1 部：設計原則及び杵組み”, JISZ8531-1, http://www.jisc.go.jp/

8）宮脇健三郎，佐野睦夫，近間正樹，上田博唯：“動作同期型調理ナビ ゲーションのための実世界対応型調理タスクモデル”，画電学誌， $\mathbf{3 6}, 3$ pp.252-263 (2007)

9）宮脇健三郎, 佐野睦夫, 西口敏司, 池田克夫：“動作同期型調理ナビグー ションのためのユーザ適応型調理タスクモデル”，情処学論， $\mathbf{5 0}, 4$ 1299-1310 (Apr. 2009)

10）浜田玲子，宮澤寛，鈴木幸敏，岡部淳，佐藤真一，坂井修一，椎尾一
郎：“コンピュータ強化キッチンによるインタラクティブ調理支援”，第 13 回インタラクティブシステムとソフトウェアに関するワークショップ (WISS2005)，pp.49-52 (2005)

11）福田司, 中内靖, 野口勝則, 松原隆: “自律移動ロボットとタッチパネルを 利用した調理作業支援システム”，機学論 (C 編)， 72, 716, pp.201-208 (2006)

12）和田淑子, 大越ひろ：“健康・調理の科学 - おいしさから健康へ”, 建 帛社 (2004)

13）厚生学働省社会・援護局障害保健福祉部，国立障害者リハビリテーショ ンセンター: “高次脳機能障害診断基準”, http://www.rehab.go.jp/ri/brain_fukyu/handankizyun.html

14）鈴木孝治, 早川裕子, 種村留美, 種村純: “高次脎機能障害マエストロシリー ズ（3）リハビリテーション評価”, pp.48-49, pp.55-57, pp.101-103, pp.130，医歯薬出版株式会社 (2006)

15）任天堂：“健康応援レシピ 1000 DS 献立全集”, http://www.nintendo.co.jp/ds/aoij/index.html

16）山鳥重，早川裕子，博野信次，三村將，先崎章：“高次脑機能障害マ工 ストロシリーズ（1）基礎知識のエッセンス”, pp.30, 医歯薬出版株式 会社 (2007)

17）任天堂：“世界のごはんしゃべる！D S お料理ナビ”, http://www.nintendo.co.jp/ds/cnvj/index.html

18）佐々木祐介，佐藤孝幸，磯辺友佳里，廣富哲也：“USB カメラを用いた 高次脳機能障害者のための作業支援システム”，信学技報， 107，436， WIT2007-55, pp. 1-6 (2008)

19）山内繁：“参加支援工学”， BME， 12, 8, 1-8 (1998)

20）浜田玲子，井手一郎，坂井修一，田中英彦：“料理テキ久卜教材におけ る調理手順の構造化”，信学論 D-II, 85, 1, pp.79-89 (2002)

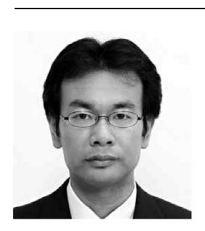

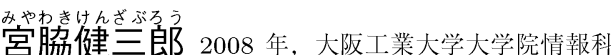
学研究科博士後期課程修了。博士（情報学）。現在，同 大学情報科学部助手. ユビキタス調理支援などコンテキ ストアウェアサービスの研究に従事.

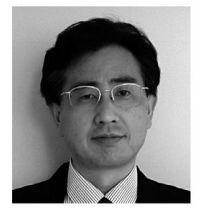

吉左野胿夫 1983 年, 京大大学院修士課程修了. 同 年, 電電公社（現 NTT）電気通信研究所入所. 2002 年, 大阪工業大学情報科学部教授，現在に至る。ロボットビ ジョン, ロボットコミュニケーション, 料理メディアの 研究等に従事。

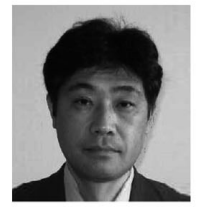

热热村 俊いち 1985 年, 新潟大学大学院工学研究科 修了. 同年 NTT 入社. 現在.NTT サイバーソリュー ション研究所主任研究員. 情報通信システムに扩ける $\mathrm{HCI}$ およびアクセシビリティの研究，人間工学の標準化に従 事. 博士 (学術).

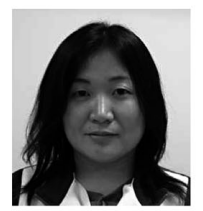

大势出道孛 1994 年, 大阪医療秘書福祉専門学校 卒業，介護福祉士資格取得．同年，大阪府立砂川厚生福祉 センター。2005 年，大阪府立身体障害者福祉センター。 2007 年, 大阪府立障がい者自立センター, 現在に至る。

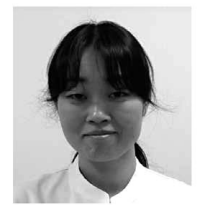

素松岡美保豆 2002 年, 自治医科大学卒. 同年大阪 府立病院. 2005 年, 大阪府立身体障害者福祉センター附 属病院. 2007 年，大阪府立障がい者自立センター兼大阪 府立急性期・総合医療センターリハビリテーション科に て診療，現在に至る。 